\title{
Interpretação histórico-social das duas narrativas de dilúvio da Bíblia Hebraica
}

\author{
Historical-social interpretation of the two flood narratives of the Hebrew \\ Bible
}

\author{
Osvaldo Luiz Ribeiro*
}

\begin{abstract}
Resumo
O presente artigo tem por tema as duas narrativas de dilúvio da Bíblia Hebraica, que, a despeito de terem sido costuradas em uma composição redacional, podem, de modo relativamente fácil, ser separadas e recuperadas. O objetivo do artigo é, portanto, recuperar as duas narrativas de dilúvio da Bíblia Hebraica, demonstrar sua integralidade e propor interpretação histórico-social para cada uma delas. $O$ texto de Gn 6,5-9,17 foi traduzido, as glosas redacionais foram identificadas, cada narrativa foi reconstituída e considerada íntegra e pronta para o procedimento hermenêutico. Conclui-se que, escrita no final do século VI, a primeira narrativa, aqui chamada de "narrativa monárquica eloísta do dilúvio" tenha tido por função a refundação do governo da golah, quando de seu retorno da Babilônia, enquanto que, escrita em meados do século $V$, a segunda narrativa, aqui chamada de "narrativa sacerdotal javista do dilúvio" tenha servido para a introdução do sacrifício substitutivo na Jerusalém então governada pelo corpo sacerdotal.
\end{abstract}

Palavras-chave: Interpretação histórico-social da Bíblia Hebraica; exegese históricosocial; exegese; Bíblia Hebraica; mito

\begin{abstract}
The theme of this article is the two narratives of the Flood of the Hebrew Bible, which, despite having been sewn into a composition, can be relatively easily separated and recovered. The purpose of the article is therefore to recover the two flood narratives of the Hebrew Bible, to demonstrate its completeness and to propose historical-social interpretation for each one of them. The text of Gn 6,59,17 was translated, the editorial glosses were identified, each narrative was reconstituted and considered complete and ready for the hermeneutical procedure. It is concluded that, written at the end of the sixth century, the first narrative, here called "Elohist monarchical narrative of the flood", had as its function the refoundation of the government of the golah, on his return from Babylon, while, written in the mid-fifth century, the second narrative, here called "Yahwist priestly narrative of the flood", served to introduce the expiatory sacrifice in Jerusalem, then ruled by the priestly body.
\end{abstract}

Key words: Historical-social interpretation of the Hebrew Bible; Historical-social exegesis; exegesis; Hebrew Bible; myth

Artigo submetido em 15 de maio de 2017 e aprovado em 02 de dezembro de2017.

* Pós-doutorado em Ciências da Religião. Doutor em Teologia - PUC-Rio. Professor do Mestrado em Ciências das Religiões da Faculdade Unida de Vitória. País de Origem: Brasil. E-mail: osvaldo@faculdadeunida.com.br.

Horizonte, Belo Horizonte, v. 15, n. 48, p. 1446-1479, out./dez. 2017 - ISSN 2175-5841 


\section{Introdução}

Estudos que me encaminharam ao doutorado sobre Gn 1,1-3, nos inícios da década de 2000, publiquei uma série de artigos sobre os textos de criação e dilúvio na Bíblia Hebraica1. A pedido do orientador, o saudoso Bouzon, a série foi interrompida. Motivado pelo fato de ter identificado, por volta de 1850, significativa alteração do verbete בָּרָ nos léxicos e dicionários de Gesenius, até então publicados, concluída em 2008 a tese ${ }^{2}$, investi algum tempo na pesquisa sobre o tratamento da raiz hebraica entre meados do século XVIII e meados do século $\mathrm{XX}^{3}$. A despeito de a série ter-se dedicado às narrativas de criação e dilúvio, o referido doutorado e as subsequentes pesquisas, decorrentes dele incidiram exclusivamente sobre aspectos específicos de parte de Gn 1,1-2,4a. Ao menos se considero textos publicados, não me aprofundei nem em Gn 2,4b-3,244, uma narrativa de criação, nem em Gn 6,5-9,17, complexo redacional que costura, imbricadamente, duas narrativas autônomas e independentes de dilúvio. Dilúvio(s): as narrativas sacerdotal e pós-sacerdotal da Bíblia Hebraica, em contexto histórico-socials foi o único texto que publiquei especificamente sobre as narrativas de dilúvio. Chegou a hora de dar alguma atenção a elas.

O geral da questão está introduzido no artigo citado, e não é necessário retornar ao que lá se discute ${ }^{6}$. Questões dadas por resolvidas são: Gn 6,5-9,17 consiste no imbricamento redacional de duas composições, literalmente, dois rolos independentes, contendo, cada um, uma estória autônoma de dilúvio7; as duas

\footnotetext{
${ }^{1}$ Cf. RIBEIRO, 2002; RIBEIRO, 2003a; RIBEIRO, 2003b; RIBEIRO, 2003c; RIBEIRO, 2005.

${ }^{2}$ Cf. RIBEIRO, 2008a. Parte da referida tese foi publicada: RIBEIRO, 2015.

${ }^{3}$ Cf. RIBEIRO, 2016.

${ }^{4}$ Cf. RIBEIRO, 2008b. Uma das poucas tentativas de abordar Gênesis 2,4b-3,24 deu-se mais por força de estudos em Cânticos dos Cânticos: cf. RIBEIRO, 2013.

${ }^{5}$ Cf. RIBEIRO, 2004.

${ }^{6}$ Todas as questões introdutórias relativas a Gn 6,5-9,17 devem ser consultadas no artigo referido na nota anterior. Plasticamente mais didática, uma versão colorida do mesmo artigo, com a distinção das duas narrativas do dilúvio em cores diferentes, o leitor pode encontrar no seguinte endereço: http://www.ouviroevento.pro.br/publicados/Diluvios.htm.

${ }^{7}$ Um quadro sintético, com a separação das duas narrativas, proposta em cada caso por G. Luzzi, W. H. Bennett, S. R. Driver, G. von Rad, A. Richardson, E. A. Speiser, O. Eissfeldt, C. Westermann, R. Koch, E. H. Maly, F. Datller, E. A. La Verdiere, G. W. Coats, L. Ruppert, G. Fohrer e E. Sellin e E. Charpentier, bem como as indicações das respectivas fontes bibliográficas onde podem ser avaliadas pode ser consultado no artigo citado, Dilúvio(s) (RIBEIRO, 2004, p. 101-104). Eu realmente solicito ao leitor que compreenda a necessidade de reportar as consultas técnicas àquele artigo, porque as dimensões do presente devem obedecer as prescrições editoriais, e repetir aqui as questões histórico-críticas já tratadas lá parece-me desnecessário.
} 
narrativas utilizadas para a composição de Gn 6,5-9,17 foram escritas em períodos diferentes, por mãos diferentes, por razões teológicas diferentes, tendo a composição sido elaborada por ainda outras mãos, de época e teologia também diferentes das anteriores; como disse Eissfeldt (1966, p. 181), é relativamente fácil a separação das duas narrativas, uma vez que o redator não teve, ou os redatores não tiveram nenhum interesse em dissimular o entretecimento das duas narrativas que usavam em sua composição. No artigo que publiquei, tratei dessas questões, analisei a pesquisa histórico-crítica e me dediquei especificamente à cronologia redacional que costurava as duas narrativas, tendo, cada uma, uma cronologia própria e distinta uma da outra, tendo sido ambas costuradas aritmeticamente em uma nova cronologia. Naquele artigo, não tratei da questão que aqui me interessa: as duas narrativas foram preservadas intactas, ou, quando a narrativa Gn 6,5-9,17 foi composta, seções originais das duas narrativas utilizadas na composição foram desprezadas, de sorte que Gn 6,5-9,17 guarda apenas pedaços das duas narrativas originais, mas não integralmente nenhuma das duas?

A questão não é da ordem da mera curiosidade. Pelo contrário! Ela respira o ambiente da pesquisa histórico-social. Se as duas narrativas foram preservadas integralmente, então é possível aplicar a elas os procedimentos da pesquisa indiciária (GINZBURG, 1989, p. 143-179 ), para tentar, por meio delas, por hipótese, reconstruir o ambiente original de sua produção, e, logo, o sentido com que foram redigidas. Se, todavia, o processo de composição desprezou seções maiores ou menores de cada uma delas, a exegese histórico-social, que depende inexoravelmente dos indícios do evento-texto, teria nas mãos duas narrativas fragmentadas, logo, incompletas, de sorte que o trabalho indiciário resultaria muitíssimo mais difícil, se é que, nesse caso, possível, do que se as duas narrativas estivessem perfeitamente preservadas tal qual foram escritas. Se integralmente preservadas, todavia, e uma vez que “textos' podem 'responder” (APEL, 2000, p.

\footnotetext{
8 "A proposta de um método interpretativo centrado sobre os resíduos, sobre os dados marginais, considerados reveladores [...]. Um saber de tipo venatório [...]. O que caracteriza esse saber é a capacidade de, a partir de dados aparentemente negligenciáveis, remontar a uma realidade complexa não experimentável diretamente [...]. Em suma, pode-se falar de paradigma indiciário ou divinatório, dirigido, segundo as formas de saber, para o passado, o presente ou o futuro" (GINZBURG, 1989, p. 149, 152 e 154).
} 
109), feitas as perguntas certas, pode-se, ao menos, postular a possibilidade de atingir-se aquela "realidade complexa não experimentável diretamente" a que se referiu Ginzburg (2007, p. 152). Nesse caso, a “realidade complexa” seria não apenas o contexto histórico-social de cada narrativa, mas, ainda mais do que isso, o jogo político-social de que cada narrativa participa, como peça fundamental.

O objetivo do presente artigo é, portanto, apenas um: após analisar detalhadamente Gn 6,5-9,17, considerar que as duas narrativas que serviram de base para a redação foram integralmente preservadas, de sorte que, depois de reconstituídas, é, em tese, possível, sempre por hipótese, propor-se interpretação histórico-social para cada uma delas. Significa dizer que em Gn 6,5-9,17 estão preservadas duas narrativas autônomas e mutuamente independentes, de épocas diferentes, elaboradas por grupos sociais diferentes, as quais podem servir de base para a proposta de interpretação histórico-social que tenha por objetivo a recuperação indiciária de sua intenção histórico-genética.

\section{Distinção entre as duas narrativas de dilúvio}

No que segue, necessariamente longo, o leitor encontrará um quadro que tem uma dupla função. De um lado, quanto ao todo, visualizar Gn 6,5-9,17. Se desconsiderada a divisão em três colunas, e lido o texto em sua ordem sequencial, linha a linha, "verso a verso", inclusive as divisões internas de cada linha, poderá ser lida a narrativa, por mim traduzida, mas conforme se poderia lê-la, na forma das diversas traduções correntes, nas Bíblias disponíveis. Todavia, a intenção é que cada narrativa possa ser lida independentemente uma da outra, e mesmo das glosas, provenientes das camadas redacionais por que passou a composição ${ }^{9}$. Para que isso fosse possível, a despeito de o texto hebraico de Gn 6,5-9,17 estar integralmente transcrito no conjunto do quadro, as duas narrativas originais foram separadas, e, além disso, as glosas foram explicitadas, cada qual em sua respectiva

${ }_{9}^{9}$ Para as camadas redacionais, mais uma vez, e pelas mesmas razões, reporto o leitor à leitura do artigo Dilúvio(s) (RIBEIRO, 2004). 
coluna. O resultado é o seguinte. Na COLUNA A, encontra-se impresso o texto hebraico que guarda a narrativa que considero mais antiga, aqui denominada "narrativa monárquica eloísta do dilúvio". Na COLUNA C, encontra-se a narrativa mais recente, aqui denominada "narrativa sacerdotal javista do dilúvio". E na COLUNA B, ao centro, os fragmentos considerados glosas.

\begin{tabular}{|c|c|c|c|}
\hline & \multicolumn{3}{|c|}{ Gn $6,5-9,17^{10}$} \\
\hline & COLUNA A & COLUNA B & COLUNA C \\
\hline Verso & $\begin{array}{l}\text { Narrativa monárquica } \\
\text { eloísta do dilúvio }\end{array}$ & Glosas redacionais & $\begin{array}{l}\text { Narrativa sacerdotal javista } \\
\text { do dilúvio }\end{array}$ \\
\hline \multirow[b]{2}{*}{6,5} & & & 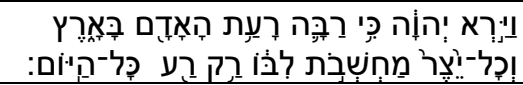 \\
\hline & & & $\begin{array}{l}\text { E viu Yahweh que grande era a } \\
\text { maldade do homem da terra. E } \\
\text { toda obra das intenções do } \\
\text { coração dele era unicamente má } \\
\text { todo o dia. }\end{array}$ \\
\hline \multirow[b]{2}{*}{6,6} & & & 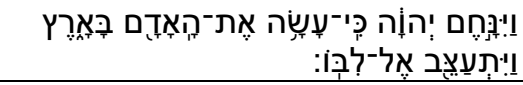 \\
\hline & & & $\begin{array}{l}\text { E arrependeu-se Yahweh, } \\
\text { porque fizera o homem da terra, } \\
\text { e enfureceu-se o coração dele. }\end{array}$ \\
\hline \multirow{6}{*}{6,7} & & & 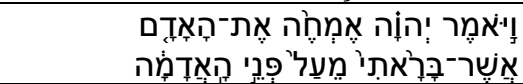 \\
\hline & & & $\begin{array}{l}\text { E disse Yahweh: "lavarei o } \\
\text { homem que criei de sobre as } \\
\text { faces do solo, }\end{array}$ \\
\hline & & 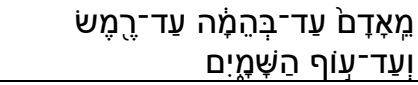 & \\
\hline & & $\begin{array}{l}\text { tanto homem quanto } \\
\text { animal quanto réptil e } \\
\text { quanto ave dos céus }\end{array}$ & \\
\hline & & & 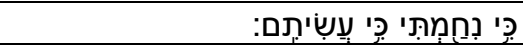 \\
\hline & & & $\begin{array}{l}\text { porque me arrependo, porque os } \\
\text { fiz eles" }\end{array}$ \\
\hline \multirow[b]{2}{*}{6,8} & & & 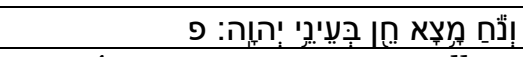 \\
\hline & & & $\begin{array}{l}\text { E Noé encontrou graça aos olhos } \\
\text { de Yahweh. }\end{array}$ \\
\hline
\end{tabular}

${ }^{10} \mathrm{Em} \mathrm{2004}$, a publicação da tradução de Gn 6,5-9,17 foi acompanhada de inúmeras notas, apensas a inúmeras palavras do texto, e ocuparam considerável extensão do artigo Dilúvios(s) (RIBEIRO, 2004). Permanecem válidas as observações críticas daquela publicação, para a qual se remete o leitor para as discussões técnicas que o o exercício de tradução suscita. 


\begin{tabular}{|c|c|c|c|}
\hline \multirow{4}{*}{6,9} & & 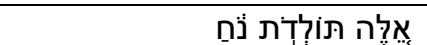 & \\
\hline & & $\begin{array}{l}\text { Estas são as gerações de } \\
\text { Noé. }\end{array}$ & \\
\hline & 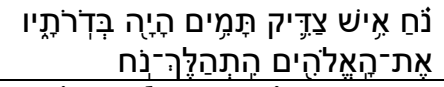 & & \\
\hline & $\begin{array}{l}\text { Noé, um homem justo, } \\
\text { perfeito era nas gerações } \\
\text { dele. Com o elohim andava } \\
\text { Noé. }\end{array}$ & & \\
\hline \multirow{3}{*}{6,10} & & 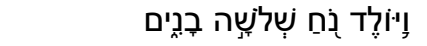 & \\
\hline & & 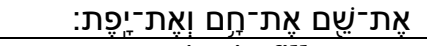 & \\
\hline & & $\begin{array}{l}\text { E gerou Noé três filhos: } \\
\text { Shêm, Hâm e Yâfeth. }\end{array}$ & \\
\hline \multirow[b]{2}{*}{6,11} & 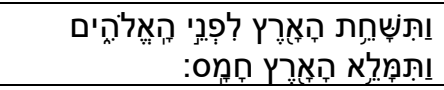 & & \\
\hline & $\begin{array}{l}\text { E corrompeu-se a terra } \\
\text { diante do elohim, e encheu- } \\
\text { se a terra de violência. }\end{array}$ & & \\
\hline \multirow[b]{2}{*}{6,12} & 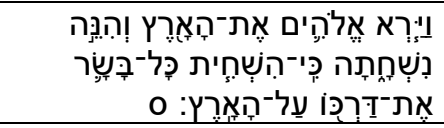 & & \\
\hline & $\begin{array}{l}\text { E viu Elohim a terra, e eis } \\
\text { corrompida, porque } \\
\text { destruíra toda carne o } \\
\text { caminho dela sobre a terra. }\end{array}$ & & \\
\hline \multirow[b]{2}{*}{6,13} & 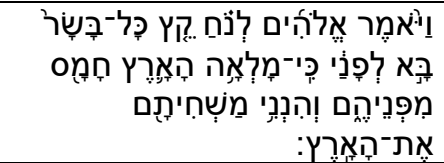 & & \\
\hline & $\begin{array}{l}\text { E disse Elohim a Noé: 'o } \\
\text { fim de toda carne veio } \\
\text { diante de mim, porque está } \\
\text { cheia a terra de violência } \\
\text { por causa deles. E eis-me, } \\
\text { destruo eles com a terra. }\end{array}$ & & \\
\hline 6,14 & & & 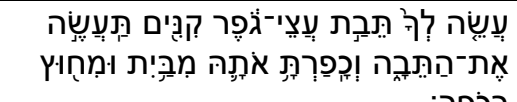 \\
\hline \multirow{3}{*}{6,15} & & & 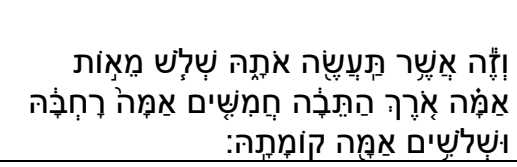 \\
\hline & & & $\begin{array}{l}\text { E é assim que farás ela: trezentos } \\
\text { côvados o comprimento da arca, } \\
\text { cinquenta côvados a largura dela, } \\
\text { e trinta côvados a altura dela. }\end{array}$ \\
\hline & & & \\
\hline
\end{tabular}




\begin{tabular}{|c|c|c|}
\hline \multirow[b]{2}{*}{6,16} & & 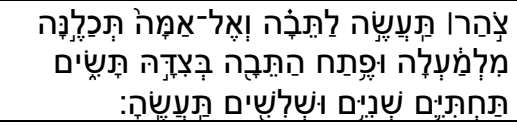 \\
\hline & & $\begin{array}{l}\text { Um teto farás para a arca, e ao } \\
\text { côvado arrematarás ele por } \\
\text { cima; e a entrada da arca no lado } \\
\text { dela disporás; inferiores, } \\
\text { segundos e terceiros farás para } \\
\text { ela. }\end{array}$ \\
\hline 6,17 & 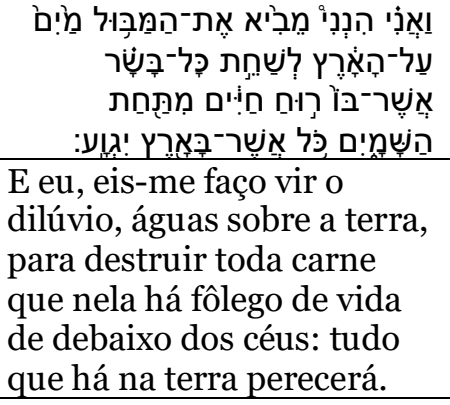 & \\
\hline 6,18 & 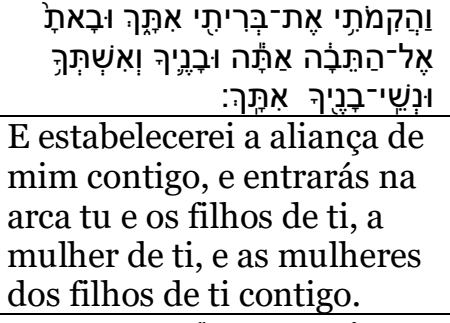 & \\
\hline 6,19 & 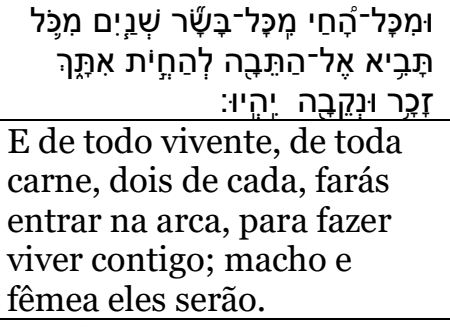 & \\
\hline 6,20 & 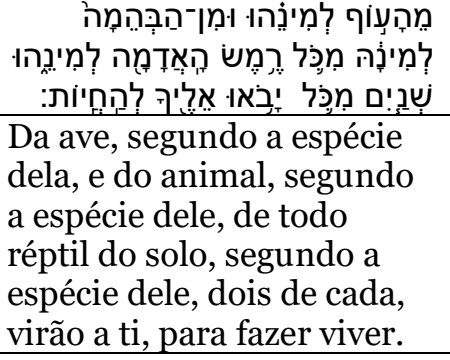 & \\
\hline \multirow[b]{2}{*}{6,21} & & 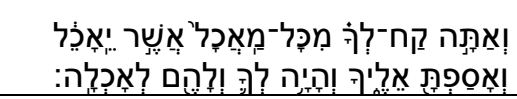 \\
\hline & & $\begin{array}{l}\text { E tu, toma para ti de toda } \\
\text { comida que será comida, } \\
\text { armazenai-a para ti; e servirá } \\
\text { para ti e para eles de alimento'. }\end{array}$ \\
\hline
\end{tabular}

Horizonte, Belo Horizonte, v. 15, n. 48, p. 1446-1479, out./dez. 2017 - ISSN 2175-5841 


\begin{tabular}{|c|c|c|c|}
\hline 6,22 & 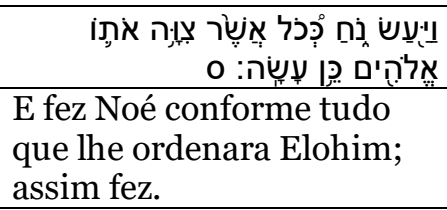 & & \\
\hline \multirow[b]{2}{*}{7,1} & & & 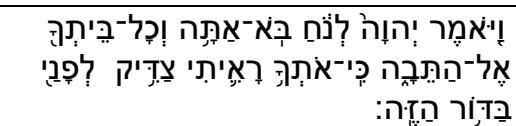 \\
\hline & & & $\begin{array}{l}\text { E disse Yahweh a Noé: 'entra tu, } \\
\text { e toda a casa de ti na arca, } \\
\text { porque te vi justo diante de mim } \\
\text { nesta geração. }\end{array}$ \\
\hline \multirow[b]{2}{*}{7,2} & & & 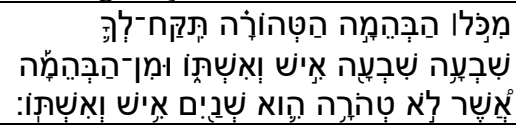 \\
\hline & & & $\begin{array}{l}\text { De todo animal puro, tomarás } \\
\text { para ti sete casais, macho e } \\
\text { fêmea, e do animal que não é } \\
\text { puro, serão dois, o macho e a } \\
\text { sua fêmea. }\end{array}$ \\
\hline \multirow[b]{2}{*}{7,3} & & & 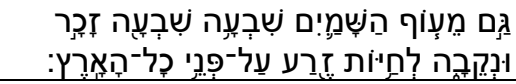 \\
\hline & & & $\begin{array}{l}\text { Também da ave dos céus, sete } \\
\text { casais, para fazer viver a } \\
\text { semente sobre a face de toda a } \\
\text { terra. }\end{array}$ \\
\hline \multirow[b]{2}{*}{7,4} & & & 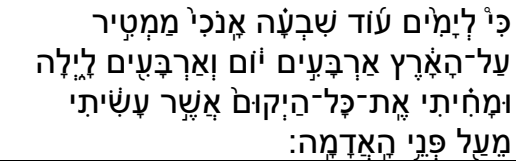 \\
\hline & & & $\begin{array}{l}\text { Porque daqui a sete dias, eu } \\
\text { farei chover sobre a terra } \\
\text { quarenta dias e quarenta noites, } \\
\text { e lavarei todo o levantado que fiz } \\
\text { de sobre as faces do solo". }\end{array}$ \\
\hline \multirow[b]{2}{*}{7,5} & & & 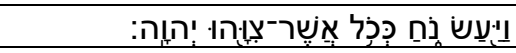 \\
\hline & & & $\begin{array}{l}\text { E fez Noé conforme tudo que lhe } \\
\text { ordenara Yahweh. }\end{array}$ \\
\hline \multirow{4}{*}{7,6} & & 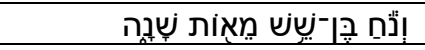 & \\
\hline & & $\begin{array}{l}\text { E Noé era filho de } \\
\text { seiscentos anos }\end{array}$ & \\
\hline & 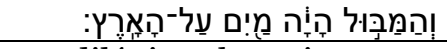 & & \\
\hline & $\begin{array}{l}\text { E o dilúvio sobreveio - } \\
\text { águas sobre a terra. }\end{array}$ & & \\
\hline \multirow{5}{*}{7,7} & & & 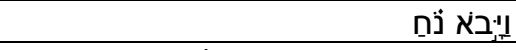 \\
\hline & & & E entrou Noé \\
\hline & & 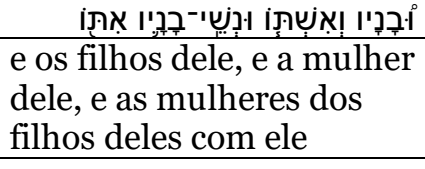 & \\
\hline & & & 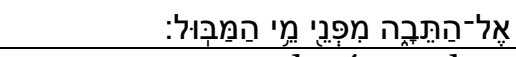 \\
\hline & & & $\begin{array}{l}\text { na arca por causa das águas do } \\
\text { dilúvio. }\end{array}$ \\
\hline
\end{tabular}

Horizonte, Belo Horizonte, v. 15, n. 48, p. 1446-1479, out./dez. 2017 - ISSN 2175-5841 


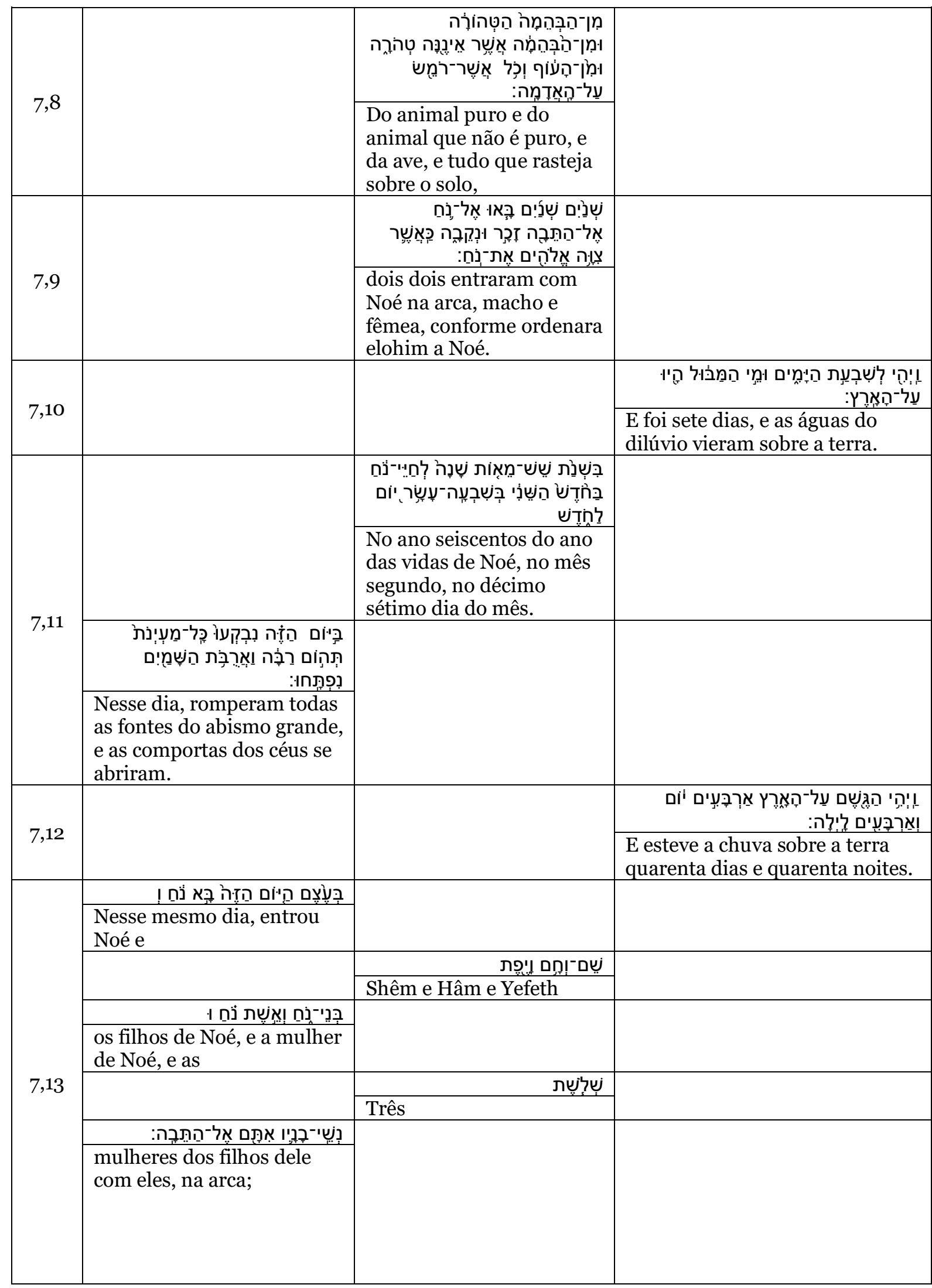




\begin{tabular}{|c|c|c|c|}
\hline 7,14 & 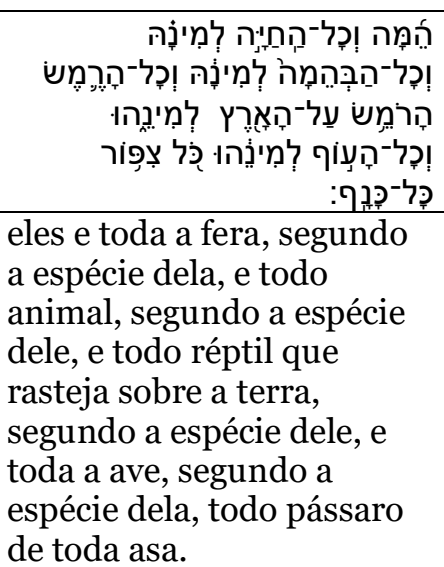 & & \\
\hline \multirow{3}{*}{7,15} & 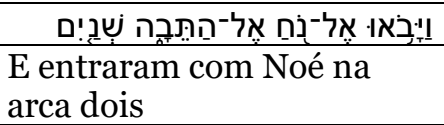 & & \\
\hline & & 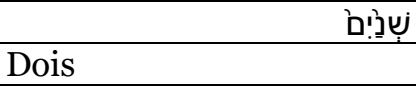 & \\
\hline & 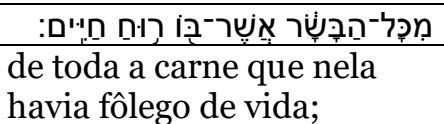 & & \\
\hline \multirow[t]{2}{*}{7,16} & 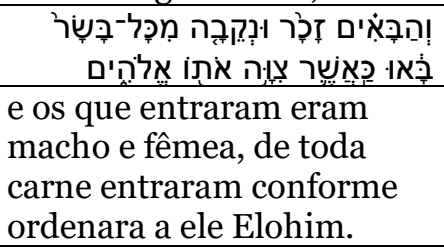 & & 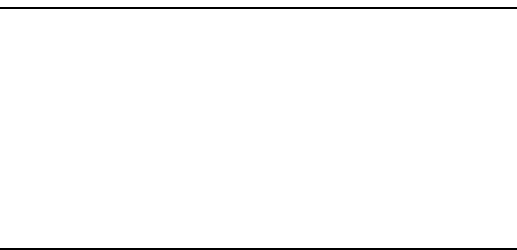 \\
\hline & & & 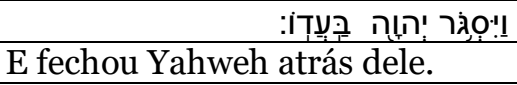 \\
\hline \multirow[b]{2}{*}{7,17} & & & 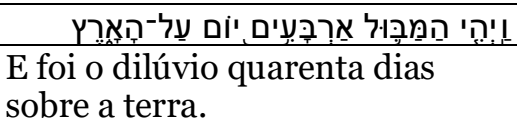 \\
\hline & 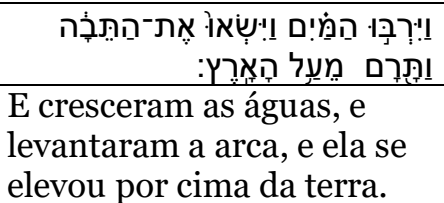 & & \\
\hline 7,18 & 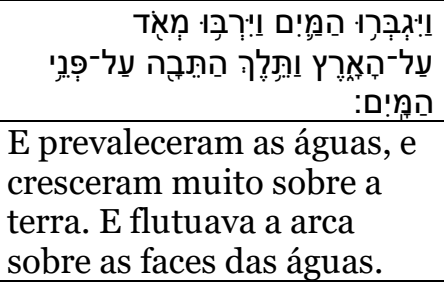 & & \\
\hline 7,19 & 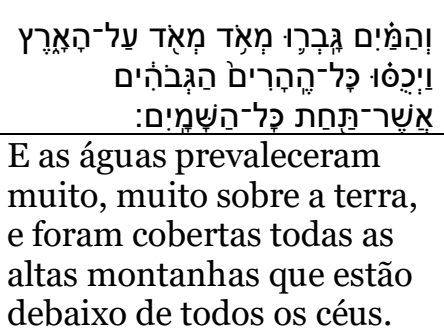 & & \\
\hline
\end{tabular}




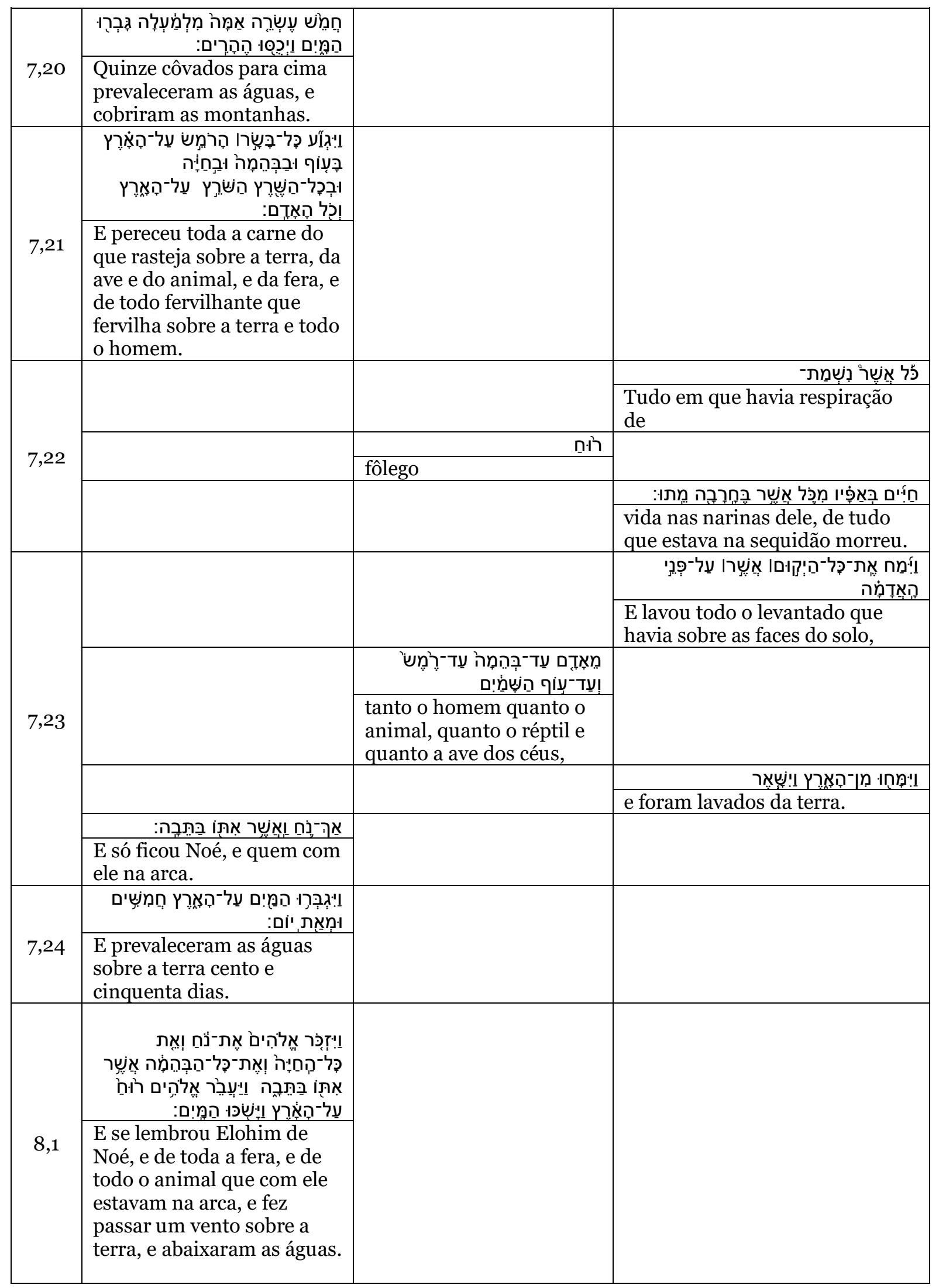




\begin{tabular}{|c|c|c|c|}
\hline \multirow[t]{3}{*}{8,2} & 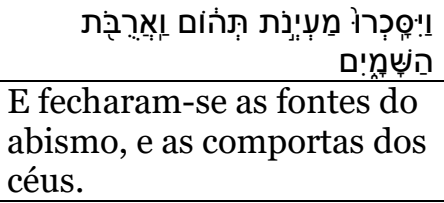 & & \\
\hline & & & 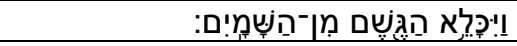 \\
\hline & & & E cessou a chuva dos céus. \\
\hline \multirow{4}{*}{8,3} & & & 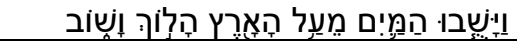 \\
\hline & & & $\begin{array}{l}\text { E retiraram-se as águas de sobre } \\
\text { a terra, indo e se retirando. }\end{array}$ \\
\hline & 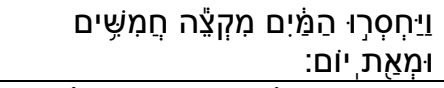 & & \\
\hline & $\begin{array}{l}\text { E minguaram as águas } \\
\text { depois de cento e cinquenta } \\
\text { dias. }\end{array}$ & & \\
\hline \multirow{6}{*}{8,4} & 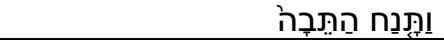 & & \\
\hline & E repousou a arca & & \\
\hline & & 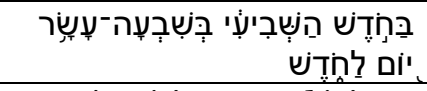 & \\
\hline & & $\begin{array}{l}\text { no mês sétimo, no décimo } \\
\text { sétimo dia do mês, }\end{array}$ & \\
\hline & עַל הָרֵּי אַרָרָטט: & & \\
\hline & $\begin{array}{l}\text { sobre as montanhas de } \\
\text { 'Arârât. }\end{array}$ & & \\
\hline \multirow{6}{*}{8,5} & 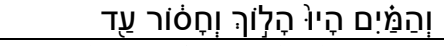 & & \\
\hline & $\begin{array}{l}\text { E as águas foram indo e } \\
\text { minguando até }\end{array}$ & & \\
\hline & & 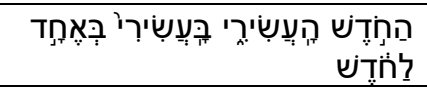 & \\
\hline & & $\begin{array}{l}\text { o mês décimo; no décimo, } \\
\text { no primeiro do mês, }\end{array}$ & \\
\hline & 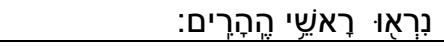 & & \\
\hline & $\begin{array}{l}\text { que apareceram os cumes } \\
\text { das montanhas. }\end{array}$ & & \\
\hline \multirow[b]{2}{*}{8,6} & & & 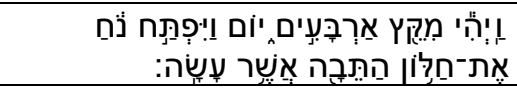 \\
\hline & & & $\begin{array}{l}\text { E foi ao fim de quarenta dias, e } \\
\text { abriu Noé a janela da arca que } \\
\text { fizera. }\end{array}$ \\
\hline \multirow[b]{2}{*}{8,7} & & & 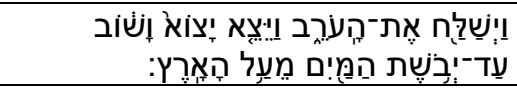 \\
\hline & & & $\begin{array}{l}\text { E soltou o corvo, e saiu, saindo e } \\
\text { retornando antes de secarem as } \\
\text { águas de sobre a terra. }\end{array}$ \\
\hline \multirow{3}{*}{8,8} & & & 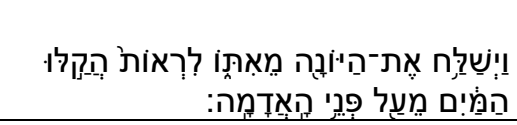 \\
\hline & & & $\begin{array}{l}\text { E soltou a pomba depois dele, } \\
\text { para ver se eram rasas as águas } \\
\text { de sobre a face do solo. }\end{array}$ \\
\hline & & & \\
\hline
\end{tabular}




\begin{tabular}{|c|c|c|c|}
\hline \multirow[b]{2}{*}{8,9} & & & 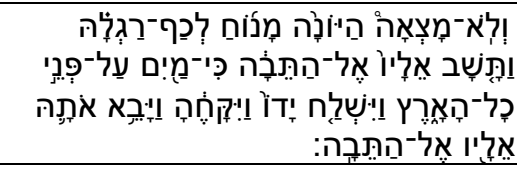 \\
\hline & & & $\begin{array}{l}\text { E ela não encontrou lugar de } \\
\text { descanso para a planta da pata, e } \\
\text { retornou para ele, para a arca, } \\
\text { porque as águas estavam sobre a } \\
\text { face de toda a terra. E estendeu } \\
\text { a sua mão, e a recolheu, e a fez } \\
\text { entrar consigo na arca. }\end{array}$ \\
\hline \multirow[b]{2}{*}{8,10} & & & 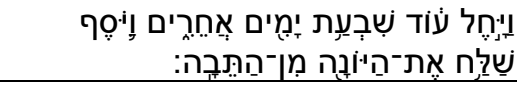 \\
\hline & & & $\begin{array}{l}\text { E aguardou ainda sete outros } \\
\text { dias, e repetiu soltar a pomba da } \\
\text { arca. }\end{array}$ \\
\hline \multirow[b]{2}{*}{8,11} & & & 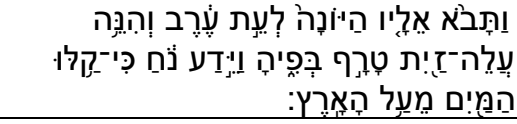 \\
\hline & & & $\begin{array}{l}\text { E veio para ele a pomba ao } \\
\text { tempo da tarde, e eis uma folha } \\
\text { de oliveira arrancada no seu } \\
\text { bico! E soube Noé que eram } \\
\text { rasas as águas de sobre a terra. }\end{array}$ \\
\hline \multirow[b]{2}{*}{8,12} & & & 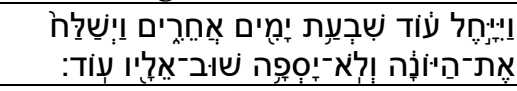 \\
\hline & & & $\begin{array}{l}\text { E esperou ainda sete ouros dias, } \\
\text { e soltou a pomba, e ela não } \\
\text { repetiu retornar para ele de } \\
\text { novo. }\end{array}$ \\
\hline \multirow{4}{*}{8,13} & & 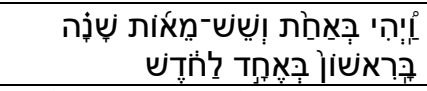 & \\
\hline & & $\begin{array}{l}\text { E foi no ano seiscentos e } \\
\text { um, no princípio, no } \\
\text { primeiro do mês. }\end{array}$ & \\
\hline & & & 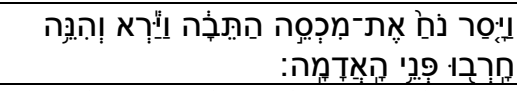 \\
\hline & & & $\begin{array}{l}\text { E retirou Noé a cobertura da } \\
\text { arca, e viu, e eis enxugaram as } \\
\text { faces do solo }\end{array}$ \\
\hline \multirow[b]{2}{*}{8,14} & & 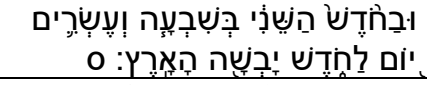 & \\
\hline & & $\begin{array}{l}\text { E no mês segundo, nos } \\
\text { vinte e sete dias do mês, } \\
\text { secou a terra. }\end{array}$ & \\
\hline \multirow[b]{2}{*}{8,15} & 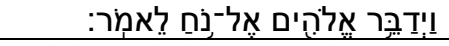 & & \\
\hline & $\begin{array}{l}\text { E falou Elohim a Noé, para } \\
\text { dizer: }\end{array}$ & & \\
\hline \multirow[b]{2}{*}{8,16} & 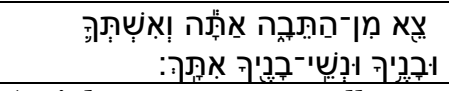 & & \\
\hline & $\begin{array}{l}\text { 'Sai da arca tu, e a mulher } \\
\text { de ti, e os filhos de ti, e as } \\
\text { mulheres dos filhos de ti } \\
\text { contigo. }\end{array}$ & & \\
\hline
\end{tabular}

Horizonte, Belo Horizonte, v. 15, n. 48, p. 1446-1479, out./dez. 2017 - ISSN 2175-5841 


\begin{tabular}{|c|c|c|c|}
\hline 8,17 & 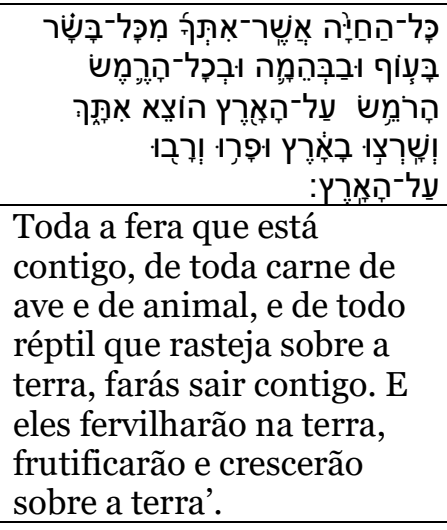 & & \\
\hline 8,18 & 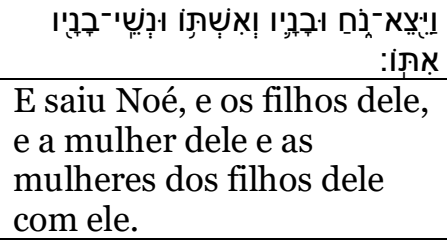 & & \\
\hline 8,19 & 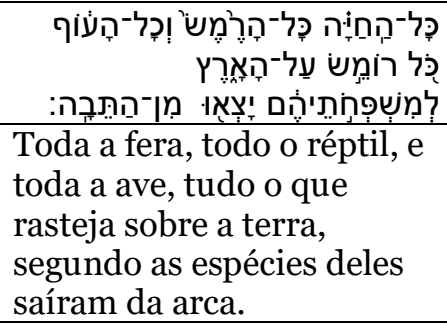 & & \\
\hline & & & 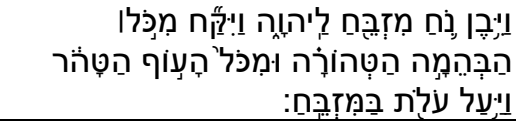 \\
\hline 8,20 & & & $\begin{array}{l}\text { E construiu Noé um altar para } \\
\text { Yahweh, e tomou de todo o } \\
\text { animal puro e de toda a ave } \\
\text { pura, e fez subir holocaustos } \\
\text { sobre o altar. }\end{array}$ \\
\hline & & & 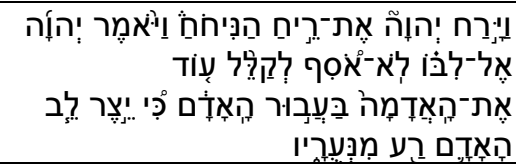 \\
\hline 8,21 & & & $\begin{array}{l}\text { E cheirou Yahweh o cheiro } \\
\text { aplacante. E disse Yahweh ao } \\
\text { seu coração: "não repetirei } \\
\text { amaldiçoar de novo o solo por } \\
\text { causa do homem, porque a obra } \\
\text { do coração do homem é má } \\
\text { desde a sua juventude. }\end{array}$ \\
\hline \multirow[b]{2}{*}{8,22} & & 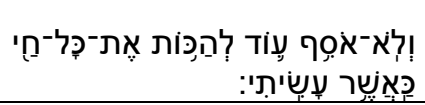 & \\
\hline & & $\begin{array}{l}\text { E não repetirei de novo } \\
\text { matar todo o vivente } \\
\text { conforme fiz }\end{array}$ & \\
\hline
\end{tabular}

Horizonte, Belo Horizonte, v. 15, n. 48, p. 1446-1479, out./dez. 2017 - ISSN 2175-5841 


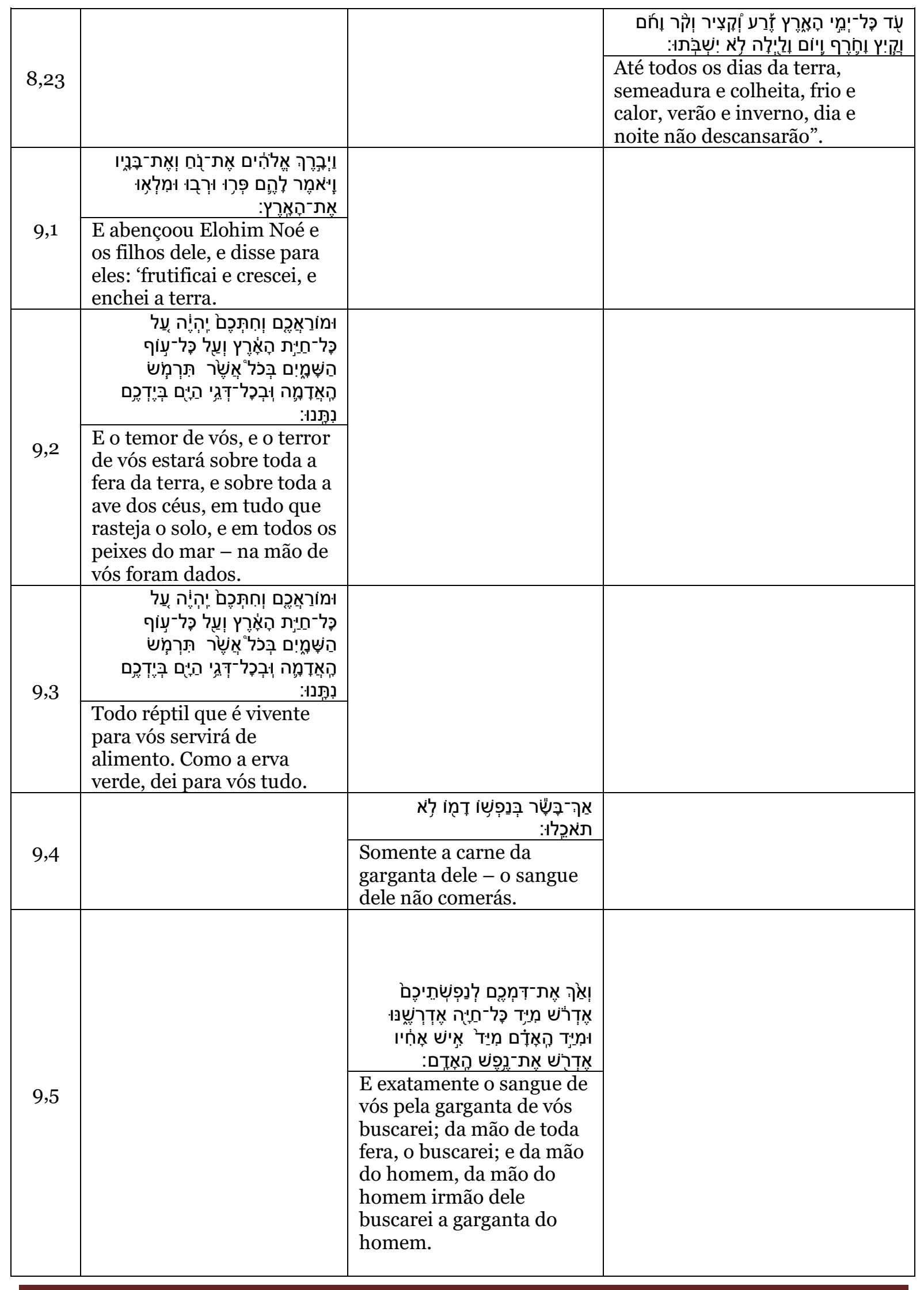

Horizonte, Belo Horizonte, v. 15, n. 48, p. 1446-1479, out./dez. 2017 - ISSN 2175-5841 


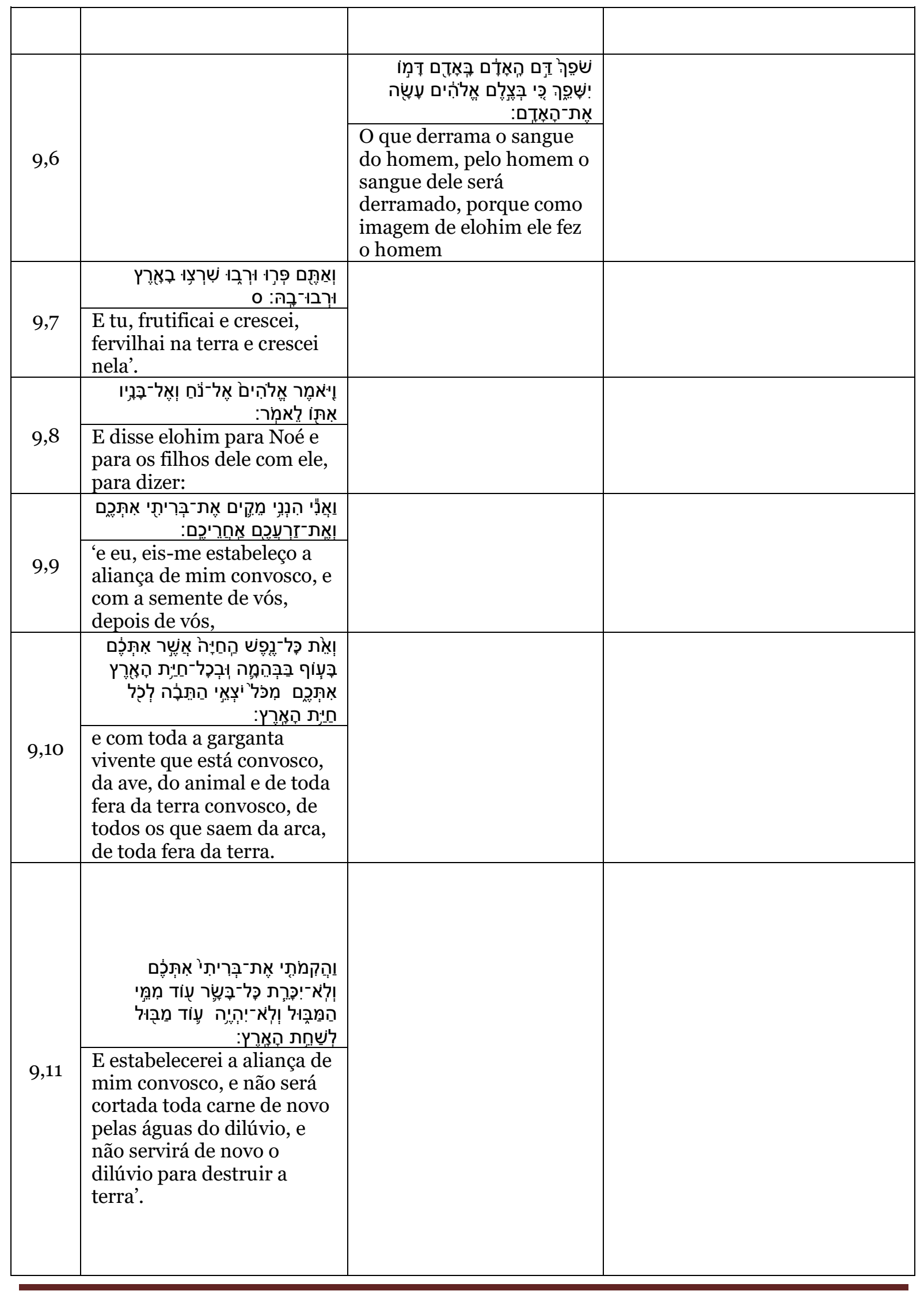

Horizonte, Belo Horizonte, v. 15, n. 48, p. 1446-1479, out./dez. 2017 - ISSN 2175-5841 


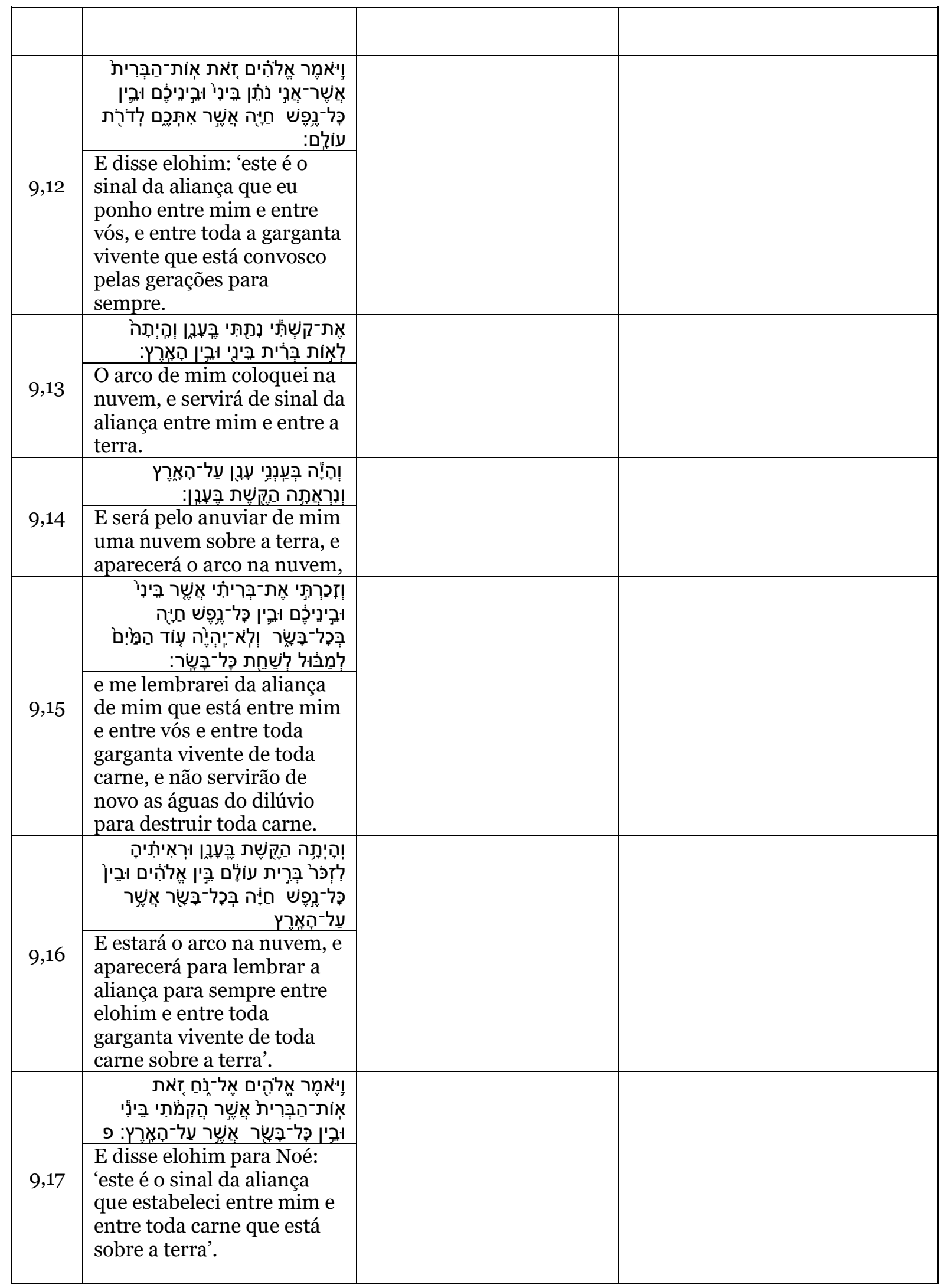




\section{Sobre possíveis, mas não categóricas, supressões de trechos dos rolos originais}

Não é possível ser categórico em relação à supressão ou não de algum trecho entre 6,8 e 6,14. A instrução por parte da divindade, para que Noé construa a arca, faz-se sem anúncio. À declaração "e Noé encontrou graça aos olhos de Yahweh" $(6,8)$, segue-se, sem qualquer anúncio de que Yahweh vai dizer alguma coisa, a fala de Yahweh: "faze para ti uma arca" $(6,14)$. Pode-se considerar que a "graça" que Noé encontrou aos olhos de Yahweh foi receber a instrução de construir a arca, com a qual, excepcionalmente, ele e sua família se salvariam da calamidade divina que se aproximava. A explicação funciona. Todavia, não é comum que os textos da Bíblia Hebraica deixem de anunciar quase que mecanicamente a fala de um

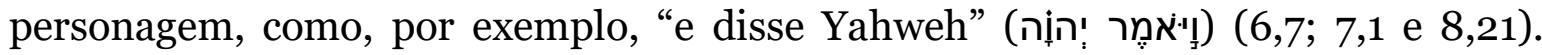
Além disso, na passagem, não há outra ocorrência de uma fala não anunciada da divindade. Isso posto, talvez seja prudente considerar a possibilidade de que, quando da composição de Gn 6,5-9,17, o redator tenha deixado de transcrever um

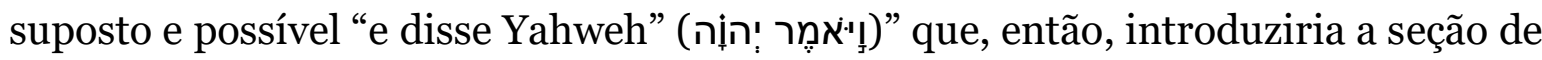
instruções da divindade sobre a construção da arca. Não é, todavia, absurdo considerar-se a hipótese de que, como sugeri, a declaração de 6,8 tenha tido originalmente essa função.

\section{Observações gerais sobre a interpretação histórico-social das narrativas do dilúvio}

Foi por força e no contexto de seu cativeiro babilônico que a relativamente pequena elite judaíta deportada - a golah - teve (pela primeira vez?) contato direto com as narrativas de dilúvio da tradição mesopotâmica (LIVERANI, 2008, p. 287305). Todavia, não foi o fato de ter tido contato com as narrativas que levou à golah a copiá-las, adaptá-las e subscrevê-la. A meu juízo, o gatilho para que, a seu tempo e modo, a golah se apropriasse do tema e, em grande parte, até da plástica literária das narrativas mesopotâmicas do dilúvio, foi disparado pelo retorno da golah 
(FINKELSTEIN e SILBERMAN, 2003, p. 397-419), por volta de 520, mais especificamente. De todo modo, penso que dificilmente antes de 539. A meu ver, quando do retorno desta, o conflito entre a golah e os remanescentes na terra (FINKELSTEIN e SILBERMAN, 2003, p. 409-412; LIVERANI, 2008, p. 313-318) instalou as condições para que, pela primeira vez, a golah atinasse a funcionalidade retórica do tema do dilúvio. As circunstâncias histórico-sociais do momento do retorno da golah, e, não se perca de vista, ainda sob a direção de um monarca, e não sob a direção de um corpo sacerdotal com prerrogativas de governo! (FINKELSTEIN e SILBERMAN, 2003, p. 412-415), responde pela decisão criativa da comunidade de retorno de, em situação de "conflito entre sobreviventes e remanescentes" (LIVERANI, 2008, p. 318), instrumentalizar, contra o povo remanescente, o tema do dilúvio. Nesse sentido, não se pode dizer que se trata, nem a primeira nem a segunda, de "narrativas de dilúvio". Não há, a meu ver, nenhuma intenção imediata de "contar-se" uma história, de narrar-se os acontecimentos passados, quando a divindade teria executado suas criaturas. Não, a intenção não é pedagógica, muito menos lúdica. Trata-se de uma batalha retórica, nos termos da qual o tema do dilúvio serve de arma, porque sua estrutura intrínseca serve perfeitamente aos interesses político-retóricos de quem o instrumentaliza. E, como bem assevera um dos historiadores que vimos de citar, "a documentação disponível (...) [foi] irremediavelmente reescrita sob a ótica da parte vencedora" (LIVERANI, 2008, p. 318).

Nesse sentido, ao menos quanto à Bíblia Hebraica, mas não duvido que o mesmo possa aplicar-se à comunidade babilônica, narrativas de dilúvio são grades retórico-instrumentais, empregadas em contexto histórico-social específico, no qual servem de argumento ou contra-argumento em face de conflitos políticosociais que, no nível ideológico, e aos olhos dos instrumentalizadores do tema, podem ser retoricamente superados por meio desse tipo de narrativa. 
Não será possível aprofundar aqui a "teoria", ou, em outras palavras, os argumentos que se poderiam elencar para a "tese" de que estamos diante de mitoplasmas políticos programáticos. Com a ressalva da ciente brevidade da referência, a leitura que, em seu excepcional capítulo "A cidade defendida por seus mitólogos", Detienne faz de A República e de As Leis, de Platão (DETIENNE, 1998, p. 151-184), poderia servir para aprofundar o argumento. Detienne descreve o projeto platônico de a "Cidade Bela" ser governada por meio de programas de controle social com base exatamente em mitoplasmas. Vale lembrar tanto a proximidade geográfica quanto a proximidade temporal entre os textos analisado por Detienne e os textos aqui analisados.

Grego, e, se meramente teórico, não vem ao caso, o programa de controle social que Detienne explicita tem todos os elementos que vejo no programa social, judaíta, que as narrativas de dilúvio, indiciariamente, me revelam. Nos termos com que Detienne se expressa, trata-se do controle social por meio da "mitologia" - a rigor, lógoi, discursos, leis, mûthoi, narrativas mitoplasmadas, mitos, e oidai, cânticos programáticos (DETIENNE, 1998, p. 176), de sorte a cobrir toda a extensão da cidade pelo controle absoluto do "rumor", “o componente fundamental da tradição", (p. 169), "pois o legislador doravante sabe que tem o poder de fazer com que se acredite em tudo o que desejar incutir na alma dos jovens" (p. 175), este deve contratar mitoplastas, que converterão em mitos as leis, e, mais tarde, as canções, os mitos, para a que cidade inteira ouça "uma única e mesma voz" (p. 184), para o sucesso de cujo empreendimento "basta que o legislador consagre essa voz pública no espírito de todos" (p. 171), mesmo que para isso se deva recorrer à "mentira necessária [...] a bela mentira útil” (p. 173). Não há lugar para ingenuidades políticas aqui: "os artesãos do Estado, poetas oficiais, terão a missão de fabricar os 'mitos' destinados a serem estampados na alma dos futuros cidadãos" (p. 176), culminando todo o processo com a expulsão física dos poetas indesejáveis (p. 177). 
Como se vê, "a mitologia ocupa inteiramente o campo do político" (DETIENNE, 1998, p. 184). O que Detienne observa em A República e em As Leis, penso poder(mos) ver na política de controle social judaíta do final do século VI em diante, e penso que isso se deva ao fato de se tratar de empreendimento próprio do modelo de administração persa, porque, afinal, "a elite leal, recrutada na comunidade de exilados judaítas na Babilônia, foi liderada por dignitários relacionados com a administração persa" (FINKELSTEIN e SILBERMAN, 2003, p. 413-414). Já tratei anteriormente da por mim postulada relação entre, de um lado, o programa de psicologia social da golah, de outro, a administração persa e, por fim, um pouco mais tarde, os tratados de Platão, e o leitor pode recuperar os argumentos gerais a partir daquela publicação (RIBEIRO, 2006, p. 10-17). Devo apenas ratificar que não considero "coincidência" que o que Detienne veja em $A$ República e em As Leis coincida espantosamente com o que, ao longo das pesquisas representadas pela bibliografia pessoal indicada no presente artigo, tem sido visto também como programa da administração judaíta no período persa.

Quanto ao que segue, isto é, minha interpretação histórico-social de cada uma das duas narrativas de dilúvio que, originalmente, tiveram a função de produzir aquilo que Detienne chamou de "rumor", vale recuperar as declarações do historiador italiano que tenho citado, que, quanto à "narrativa bíblica (em que um redator sacerdotal [...] fundiu duas narrativas paralelas)" (LIVERANI, 2008, p. 292), diz não ter "outro valor histórico senão o que se refere ao ambiente em que foram concebidas ou reelaboradas, em conexão com o clima cultural de então" (p. 291). Liverani disse que “a narrativa do dilúvio (...) é, portanto, um ‘típico' mito de fundação" (p. 292). E eu acrescentaria - sim!, mas não apenas a narrativa, isto é, a composição redacional constante em Gn 6,5-9,18 que, Liverani reconhece, é o imbricamento de duas narrativas anteriores. Na verdade, cada uma das duas narrativas, em seu momento de gestação, foi, para todos os fins políticos e sóciopsicológicos, um mito fundante. E é o que pretendo, ao menos incipientemente, demonstrar. 


\section{Interpretação histórico-social da narrativa monárquica eloísta do dilúvio}

Se estou certo em afirmar que é a circunstância do conflito político-social entre a golah e o povo remanescente o contexto responsável pelo gatilho que dispara o processo de instrumentalização do tema mesopotâmico do dilúvio em Judá, a primeira narrativa de dilúvio da Bíblia Hebraica teria sido escrita em algum momento entre 539 e 515, talvez ao mesmo tempo e em íntima associação com a narrativa de Gn 1,1-2,4a, e, a meu juízo, serviu de arma retórica contra os argumentos do povo da terra de que a golah fora alvo do castigo de Yahweh, que, por causa de sua culpa, os expulsou da terra, nesse caso, havia já quase um século.

Em linhas gerais, na tentativa de superar e derrotar seus adversários autóctones, os elementos que levam do conflito entre a golah e o povo remanescente em Judá à instrumentalização do tema do dilúvio pelos deportados em retorno parecem-me os seguintes. Primeiro, o conflito em si (LIVERANI, 2008, 267-308). Encerradas as etapas entre os primeiros assaltos babilônicos, as sucessivas ondas de destruição e deportação e a destruição definitiva de Jerusalém, o que até então constituíra Judá resume-se, agora, grosso modo, a duas comunidades: muito menor do que a outra, uma, constituída pela elite políticoreligiosa da nação, deportada na Babilônica, e a outra, muito maior do que aquela, constituída basicamente de camponeses e a gente mais miúda das cidades, que permanece em Judá e continua sua vida, agora sem a presença das antigas autoridades de Jerusalém (FINKELSTEIN e SILBERMAN, 2003, p. 410). Pode-se recolher de Ez 33,23-29 a conclusão de que, tão cedo quanto o momento das primeiras deportações, instalou-se conflito retórico-ideológico entre cada uma das comunidades, a golah e os remanescentes. É provável que o arsenal retórico tenha sofrido alterações com o tempo, até que a identidade de ambas as comunidades se amalgamasse psicológico-socialmente. Sempre sob o signo do provável, parece justo considerar que não se altera significativamente o quadro no período que vai da destruição propriamente dita de Jerusalém, o golpe fatal na elite judaíta, até, 
com a conquista da Babilônica pelos persas, a possibilidade, conquanto ainda não o fato, de retorno da golah. Considera-se que a golah não se tenha movimentado em 539, mas somente no final do século, por volta de 520. É nesse momento que os interesses dos descendentes das gerações deportadas e os descendentes dos remanescentes na terra de Judá entram em conflito, porque estes pretendem manter as posses adquiridas após a tragédia há um século, ao passo que aqueles, ao contrário, pretendem recuperar suas propriedades, posição e poder, sempre divinamente garantidos (LIVERANI, 2008, p. 312-218). Esse conflito é o gatilho que dispara a ideia criativa, e, cá entre nós, admirável!, da instrumentalização da narrativa do dilúvio, com a qual a golah teve contato por décadas (LIVERANI, 2008, p. 290-293). Recepcionada pela resistência do povo remanescente, arrostava-se-lhe o fato de terem sido os deportados objeto da ira divina, de sorte que não tinham mais condições de pretender retornar ao ofício da representação de Yahweh, e o fato revelava-se incontestável, em tese, já que, efetivamente, a golah fora expatriada, expulsa, o que pode ser muito facilmente interpretado como castigo divino. E, se fora a golah objeto de castigo divino, que lógica preside a pretensão de retornar ao seu posto de representante da divindade que promoveu o castigo? Esses, os argumentos dos remanescentes (RIBEIRO, 2006, p. 24-26). O contra-argumento da golah é extraído, genialmente, do tema do dilúvio.

A narrativa do dilúvio, basicamente, estrutura-se em torno de um eixo fundamental: determinada terra vai ser totalmente destruída pela divindade, o que se dá por explícito castigo, e, todavia, a divindade decide preservar em vida um pequeno núcleo. Preservando da destruição seu(s) escolhido(s) - em uma canoa, em uma arca (que vai pousar nas montanhas de Ararat!) -, a divindade pode aplicar o máximo castigo ao povo que permanece na terra, terra essa que é, ela sim, o objeto da punição. Com um golpe retórico genial, a golah se apropria de dois elementos retóricos e, ideologicamente, ganha a batalha. De um lado, serve-se da acusação do povo da terra de que a prova de a golah ter sido castigada pela divindade era o fato de que foi expulsa da terra, ou seja, foi para o cativeiro babilônico. Ao menos nesse primeiro momento, porque, questão relevante, ainda 
não é uma comunidade sacerdotal (LIVERANI, 2008, p. 267-286; FINKELSTEIN e SILBERMAN, 2003, p. 412-415), a golah ratifica metade do argumento, isto é, assume a declaração de que foi retirada da terra e levada para a Babilônia, mas inverte o sinal com que o acontecimento histórico é lido pela comunidade que enfrenta: a golah ter sido levada para o cativeiro não é sinal de castigo, mas de salvação - a golah não foi castigada pela divindade, foi preservada por ela! Quem permaneceu na terra é que foi objeto do castigo divino, sendo tragado impiedosamente pelas águas do dilúvio. Sim, a golah empregou a narrativa do dilúvio como uma espécie de alegoria pré-fabricada para explicar, a seu critério, sua condição de desterro, passando a considerar aquilo que o povo da terra considerava castigo como, agora, salvação. "Noé” não é outra coisa que não a golah hipostasiada. O dilúvio não é outra coisa que não a destruição de Jerusalém. A “arca” não é outra coisa que não a Babilônia. Os mortos pelo dilúvio não são ninguém mais, ninguém menos, do que o povo da terra, cuja condição de permanência em Judá é lida teológico-alegoricamente como morte pelo castigo das águas do dilúvio divino. A saída de "Noé" da arca não é outra coisa que não o retorno da golah para Jerusalém. A aliança da divindade com "Noé" não é outra coisa que não o restabelecimento da elite jerosolimitana, deportada havia quase cem anos, ao status quo de governo e elite locais.

Em termos indiciários, há marcas quanto a tudo isso na narrativa. Tratemos delas. Primeiro, "Noé” (isto é, a golah) é prontamente declarado justo, sua justiça contrastando com a falta dela em todos ao seu redor, declarados estes os responsáveis pela degradação da terra, e, logo, pela decisão soberana da divindade de trazer as águas do dilúvio. Essa declaração de justiça precisamente resiste à acusação do povo remanescente de que a golah foi deportada por sua injustiça.

Segundo, um “dado marginal” (GINZBURG, 2007, p. 149), "Noé” não constrói a arca. Não se interprete a ausência da declaração da divindade quanto a dever "Noé" construir a arca como indício da má preservação da narrativa original, agora costurada em Gn 6,5-9,17. “Noé” não constrói a “arca”, porque, em chave 
alegórico-teológica, a "arca" representa a Babilônia. Com efeito, depois que as águas cobrem todas as montanhas, a “arca” vai pousar lá nas montanhas de Ararat, e isso porque a golah tem de assumir o fato histórico - o cativeiro, e cativeiro, lá, "nas montanhas de Ararat" -, mas o faz lendo-o sem sentido positivo, e não com o sentido negativo da crítica comunidade da terra. Logo, sem ter sido construída por "Noé”, ou seja, providenciada pela própria divindade, e pousando nas montanhas do extremo norte, a “arca” representa o próprio cativeiro, que não é mais cativeiro, mas espaço de preservação dos justos.

Terceiro, diferentemente do que será dito na outra narrativa do dilúvio, nessa, escrita no final do século VI, a divindade ordena que "Noé" o faça, e, então, "Noé” sai da arca. Como não poderia deixar de ser, porque, se não sai da "arca”, isso só poderia significar que "Noé” não retornaria para sua terra, "Noé" sai da arca, e isso quer representar, sempre teológico-alegoricamente, o retorno da golah, dos justos, dos escolhidos do deus...

Quarto, e marca plasticamente fundamental da narrativa monárquica eloísta do dilúvio, a divindade celebra uma aliança com "Noé”. A palavra ("aliança”) estrutura aquela que é, cronologicamente, a primeira narrativa de dilúvio da Bíblia Hebraica. Ela aparece uma vez, na primeira parte da narrativa, em 6,18, no momento em que, anunciando o dilúvio que vai destruir a terra, não sem antes o deus preservar seu justo escolhido, a divindade antecipa que firmará uma aliança com "Noé”, e דִִִּ volta a repetir-se por simbólicas e significativas sete vezes no epílogo da narrativa (6,9.11.12.13.15.16.17), após "Noé” sair da arca, isto é, naquela seção do enredo em que se representa o retorno da golah e a retomada de seu status quo. O total de sete citações da palavra "aliança” se alcança pelo recurso retórico de estender forçadamente o discurso, de duplicar as declarações, de estender-se, de modo a se poder empregar o termo político-teológico tantas vezes quanto necessárias para o efeito retórico pretendido. "Aliança” é a palavra-chave da primeira narrativa de dilúvio, e surpreende-me que aquele historiador italiano já 
tantas vezes citado, quando escreve sobre "o profetismo do retorno e a "nova aliança" (LIVERANI, 2008, p. 277-280), e investindo ainda outras páginas na discussão contextual e histórico-social justamente da narrativa do dilúvio (LIVERANI, 2008, p. 290-293), atribua aos textos “proféticos” a temática, e não a mencione uma única vez sequer, na discussão sobre Gn 6,5-9,17...

Deve-se insistir no fato de que não se está diante de uma narrativa produzida, ideologicamente, por e para um corpo sacerdotal instalado no poder. Sem descartar a hipótese de que funcionários do rei - Zorobabel -, sacerdotes, na prática, componham a narrativa, ela é fundamentalmente obra da ideologia real. Ao contrário da narrativa que será escrita entre cinquenta e cem anos mais tarde, esta sim indiscutivelmente sacerdotal, a narrativa eloísta, isto é, aquela redigida, da mesma forma que Gn 1,1-2,4a, tendo Elohim, e não Yahweh, como nome da divindade, é uma peça da monarquia - por isso a denominei "narrativa monárquica eloísta do dilúvio”. Ela representa aquele estágio do processo de retorno definitivo da golah em que, liderada por Zorobabel, alegado representante da dinastia e real e herdeiro do trono, personagem a quem se reputa a obra de reconstrução da Grande Organização de Jerusalém (LIVERANI, 2008, p. 312-2313), especificamente, do templo, enfrentando a resistência popular, a golah elabora ou reelabora o discurso de que a divindade chancela o retorno da coroa por meio da "aliança”. Trata-se de um recomeço, de uma nova criação, pela qual responderá a narrativa de Gn 1,12,4a, depois da ação purificadora do soberano divino, nos termos da qual a divindade estabelece uma aliança com "Noé”, isto é, a golah, a saber, a coroa (RIBEIRO, 2015). Dilúvio e criação, portanto, respondem alegóricoteologicamente, e retórico-politicamente, aos dois polos do Grande Acontecimento: a destruição de Jerusalém, dilúvio, destruição dos injustos e preservação dos justos escolhidos, a golah, e a reconstrução de Jerusalém, cujo governo, por meio da “aliança”, a divindade entrega a "Noé”, isto é, à golah, ou seja, na prática, Zorobabel. 


\section{Interpretação histórico-social da narrativa sacerdotal javista do dilúvio}

Também integralmente preservada, a narrativa sacerdotal javista do dilúvio foi escrita, a meu juízo, alguma coisa entre cinquenta e cem anos após a primeira narrativa de dilúvio. Didaticamente, pensemos em 450, conquanto não haja impedimentos para uma data em torno de 475 ou 425. Já não se trata de uma narrativa monárquica. Zorobabel desapareceu sem deixar vestígios, os sacerdotes constituem a força de governo efetivamente instalada, e a narrativa monárquica eloísta do dilúvio não tem mais qualquer serventia retórico-política, porque ela não representa mais a hipóstase teológico-alegórica da infraestrutura político-social efetivamente posta. Mais do que isso, as questões histórico-sociais que se enfrentam são totalmente outras, em relação àquelas a que se respondeu com a primeira narrativa.

Os indícios que permitem a interpretação da narrativa como projeção teológico-sacerdotal do programa político-religioso do corpo sacerdotal assunto ao poder em Jerusalém são abundantes e, se for recusada a presente elaboração retórica, há de se propor interpretação alternativa, mas que dê conta de explicar a abundante relação de encaixes entre a hipóstase mitológica elaborada, a narrativa em que é consubstanciada, e a infraestrutura político-social em que é engendrada.

Vamos aos elementos. Primeiro, Se, na primeira narrativa, o "Noé" que representa a golah não podia ter construído a "arca", já que a "arca" era a Babilônia, nessa, "Noé" recebe ordens expressas de Yahweh para que a construa, e parte significativa da narrativa é gasta, inclusive, com a descrição dos termos da ordem divina. A explicação me parece bastante simples: na narrativa sacerdotal javista do dilúvio, "Noé" não é mais hipóstase da golah que foi para a Babilônia e que retorna, mas, agora, é a hipóstase do corpo sacerdotal que assumiu o poder com o vácuo monárquico. E, se "Noé" representa, como penso, os sacerdotes empoderados, a "arca" não representa outra coisa que não o templo de Jerusalém. 
Da mesma forma, ao contrário da narrativa anterior, "Noé" não é já de início declarado justo e, por isso, preservado. A condição de "justiça" de "Noé" é dada após a construção, por ele, da arca: somente em 7,1, depois da ordem de construção do templo, digo, da "arca", é que "Noé" é declarado justo.

A série dispõe de mais elementos. Uma vez que todo seu interesse é inteiramente sacerdotal, não se há de concluir a narrativa sem aquilo que representa a concentração máxima do poder sacerdotal - o rito. De fato, ao final da narrativa - seu núcleo teológico -, "Noé” realizará um extraordinário - e realmente inimaginável - sacrifício, no qual um de cada animal puro que fora preservado na arca será sacrificado a Yahweh. Ora, a questão do sacrifício impõe à narrativa um detalhe para o qual o mitoplasma monárquico não dispensara absolutamente qualquer atenção: a distinção entre animais puros e impuros. Na primeira narrativa, indistintamente, um casal de cada animal é preservado na arca. Não há distinção alguma entre animais puros e impuros. Naturalmente, porque a narrativa não opera sob o regime sacerdotal, mas monárquico. Alterada a consciência político-religiosa que o (re)elabora, logo, seu programa de controle social, o mito deve hipostasiar o respectivo mundo de onde emerge como peça político-retórica, e a marca distintiva desse mundo, sacerdotal, é a distinção entre puro e impuro. Assim, a nova narrativa é específica: sete casais de animais puros e um casal de animais impuros foram preservados. Pronto, agora "Noé", ou seja, o sacerdote no poder, pode realizar seu espetacular sacrifício jamais alguma vez realizado...

Mas nem ainda assim se chegou àquele nível da narrativa em que as entranhas sacerdotais, sua teologia, sua índole, se expressa indisfarçadamente. Pois bem, é hora de explicitá-lo. A narrativa começa com a declaração de Yahweh de que todo homem é mau. Tendo declarado a maldade inerente de todo homem - isto é, de todo camponês e homem judaíta! -, a narrativa descreve o estado psicológico da divindade - fúria: "e enfureceu-se o coração dele" $(6,6)$. Plasticamente, Yahweh é descrito como um deus colérico, tomado de fúria, que despeja sobre judaítas a sua 
fúria teologicamente justificada: eles são maus e, sendo maus, não podem permanecer, e de fato, não permanecem de pé diante da fúria do deus criador, que os fizera, mas se arrepende de ter criado “o homem da terra” $(6,6)$. Enfurecido, pois, Yahweh "lava” todos os "levantados", expressões que respondem, obviamente, pela íntima relação que essa narrativa guarda com Gn 2,4b-3,24, tanto quanto a primeira narrativa do dilúvio guardava relações também muito íntimas com Gn 1,12,4a. São pares. Não são quatro narrativas, mas duas narrativas duplas de dilúvio e criação.

O corpo da narrativa sacerdotal assemelha-se ao corpo da narrativa monárquica. Os detalhes são diferentes, a cronologia, a causa específica do dilúvio, mas, em linhas gerais, trata-se de descrever o mesmo fenômeno: a população, diante da qual se põem os redatores de cada uma das duas narrativas, lá, a coroa, cá, o templo, são julgados teologicamente culpados, e a divindade, de um lado, os destrói, e, de outro, elege os redatores das narrativas como seus representantes em Judá. Conquanto haja variação nos detalhes, está-se diante do mesmo enredo. Já o epílogo da narrativa sacerdotal, tem dimensões teológicas que não são sequer arranhadas pela relativa simplicidade retórica do texto monárquico.

De novo, "resíduos [...] dados marginais, considerados reveladores" (GINZBURG, 2007, p. 149), quando o dilúvio termina, "Noé” não sai da "arca". Nem poderia, porque a "arca", já disse, representa o quartel-general sacerdotal - o templo. "Noé", isto é, os sacerdotes, apenas retiram o teto da arca e, como não?, constrói um altar. Não vejo confirmação maior para que, nessa narrativa, a "arca" represente o templo11... No altar que "Noé" constrói, ele sacrifica um número incontável de animais. A fumaça do grande, do extraordinário sacrifício sobe até Yahweh... A fumaça atinge as narinas de Yahweh. Enfurecido, vindo de "lavar", dissolver e destruir todos os homens da terra - exceto os seus representantes! -,

\footnotetext{
${ }^{11}$ O fato de que, na narrativa, o altar é construído dentro da arca, enquanto, em Jerusalém, o altar está instalado fora do templo deve merecer a seguinte explicação: não se trata tanto do altar, quanto do templo. Na narrativa, a intenção é vincular o altar ao templo, e o fato de nela Noé não sair da arca imprime vínculo ideológico máximo à relação entre o sacrifício necessário e o lugar oficial no qual ele deve ser realizado. $O$ destinatário original do mitoplasma reconheceria Noé como o sacerdote e a arca como o templo.
} 
Yahweh é atingido em cheio pelo cheiro aplacante, o "aroma [...] calmante, sedativo, que acalma, aplaca"12. Agora se pode compreender: as dimensões ciclópicas do sacrifício correspondem ao estado de fúria da divindade. Para aplacar a fúria do deus enfurecido, cujo estado psicológico produz a hecatombe de sua própria criação, somente um sacrifico de dimensões igualmente ciclópicas!, e, não se perca de vista, somente alguém como "Noé”, e, ainda assim, instalado na “arca”, operando seu magnífico altar...

E o resultado é formidável! Resultado da eficiência do rito de aplacamento da fúria divina, Yahweh se acalma, como que sedado, e reflete sobre, de um lado, o status do homem da terra, que ele criou, e, de outro, sobre sua ação desmedida. De um lado, o homem da terra é mau, e nada há que se possa fazer a respeito. Era mau, antes do dilúvio, e continua mau. Quanto a isso, nada há que se possa fazer, porque se trata de uma condição intrínseca - os homens da terra são maus desde que nascem, e seus pensamentos são maus e apenas maus. O juízo se repete, sem alteração, no começo $(6,5)$ e no fim $(8,21)$ da narrativa, antes e depois da fúria, antes e depois da ação sacerdotal, quero dizer, do sacrifício de "Noé". Nada mudou quanto ao estado teológico do homem - mau, culpado, digno de morrer. O que muda, então? O comportamento de Yahweh. Aplacado pelo sacrifício, ele decide não matar mais o homem da terra. A fúria contenta-se, se aplaca, com os animais degolados e incinerados, que fúria de sangue é fúria de sangue, e de sangue e fúria entende o rito sacerdotal.

O leitor capta a "moral da história”? Trata-se do protótipo modelar políticoteológico do sacrifício substitutivo, do rito de expiação. Servindo-se retoricamente do contexto do dilúvio, a narrativa plasma o roteiro teológico do templo de Jerusalém, que servirá de base teológico-cultural da plataforma de governo sacerdotal jerosolimitana. Todo judaíta é mau e, sendo mau, é objeto da fúria divina. Tomado de arrependimento por tê-lo criado, e movido de fúria justiceira, Yahweh há de matar cada judaíta culpado, cada homem da terra, como fez no

\footnotetext{
${ }^{12}$ SCHÖKEL, 1997, p. 434.
} 
dilúvio, e de novo fará, tão somente seu estado de sedação seja interrompido por nova onda de fúria. O destino de todo judaíta está traçado: morrer, esmagado pela fúria da divindade, arrependida e irada com a maldade que caracteriza o coração desse desgraçado ser. Para ele, resta apenas uma e uma única porta de salvação: recorrer ao sacerdote. O sacerdote não pode fazer com que o estado de condenação a que a divindade sentencia o homem da terra seja suspenso ${ }^{13}$, mas, e isso é o mais importante!, o sacerdote pode aplacar a ira do juiz e carrasco, sedá-lo, acalmá-lo, reter sua mão furiosa. Como? Simples - basta que cada judaíta, camponês, basicamente, mas não apenas ele, senão todo judaíta, vá ao templo, leve um animal ou compre-o lá mesmo, entregue ao sacerdote, que executará o rito de expiação, e, a despeito da condenação - que permanece! - a fúria de Yahweh se adia, e o judaíta ganha novo tempo, nova vida, até o próximo sacrifício...

Propõe-se aqui que a narrativa sacerdotal javista do dilúvio seja o ato inaugural da teologia de expiação em Jerusalém. Sinto-me tentado a dizer que, antes dela, não se praticava sacrifício substitutivo, e que a sua função é, especificamente, instalar a teologia da expiação da culpa, por meio do sacrifício cruento, no templo de Jerusalém. Não estou dizendo que antes dela não se realizavam sacrifícios cruentos em Judá, mas quero acreditar que, antes dela, os sacrifícios cruentos se davam na forma de comida para a(s) divindade(s), conforme o modelo comum que a história das religiões conhece. Se a proposta estiver correta, estamos diante de uma peça que tinha por objetivo alterar profunda e substancialmente o imaginário coletivo de um povo inteiro, e que, a julgar pela história de Judá, e, inclusive, de todo o Ocidente cristão, é, sem outra que lhe rivalize em sucesso, o mais bem sucedido mitoplasma derivado da Bíblia Hebraica.

\footnotetext{
${ }^{13}$ Aliás, se isso for feito, o jogo sacerdotal acaba, e é por isso que até hoje não foi efetivamente suspenso por nenhuma teologia
} eclesiástico-institucional, por mais "libertadora” que se apresente. 


\section{Observações finais}

Como tentei, ainda que brevemente, demonstrar acima, as duas narrativas do dilúvio da Bíblia Hebraica não são, a rigor, narrativas que tenham interesse direto em contar uma história de dilúvio. O dilúvio aí é meramente incidental, instrumental. Instrumentaliza-se a tradição mesopotâmica do dilúvio como base para a elaboração retórica de, no primeiro caso, reação contra a ofensiva popular em face do retorno da golah, e, no segundo caso, ação de mudança radical do paradigma teológico de Judá, transformado, de uma antiga comunidade de modelo tributário monárquico, em uma comunidade agora teologicamente sacerdotal, em cujas rotinas de administração os processos de controle psicológico-teológico presidem as rotinas político-sociais.

Não se trata de "memória popular". Se o arrazoado está correto, nem "criação", muito menos "dilúvio", são pacotes da semiótica cultural popular. Ao menos, para o que há de popular em Judá. No caso do tema do dilúvio, trata-se de mitoplasma importado da Babilônia, pela golah, e, no primeiro caso, instrumentalizado em programa monárquico de refundação da coroa, sempre sob o argumento mitológico do fundamento divino, nesse caso, a aliança entre a golah "Noé" - e a divindade. No segundo caso, a deliberação soberana de um deus fleumático, impassível, um estadista celeste, de destruir burocraticamente a terra, converte-se na ação patológico-pulsional de uma divindade tomada de fúria, motivo necessário para a venda eficiente da instrumentalidade de um aparelho de governo, cuja funcionalidade se prende a, por meio de ininterruptos e incessantes ritos, aplacar a jamais completamente aplacada ira desse deus furibundo... Diante de meus olhos, a cena me faz recordar da invasão das praças públicas brasileiras, nas décadas de 6o, daquela gente de Bíblia na mão, a projetar em telões gigantescos as cenas horripilantes do inferno, e também de um deus, senhor dos infernos, ao fim de cuja exibição os herdeiros daquele mesmo aparelho sacerdotal, 
com o mesmo programa político-teológico, vendem a sua instrumentalidade - e seu poder - na forma do que Hebreus 10,12 gostou de chamar de "um sacrifício único pelos pecados”...

Para encerrar esta, como disse, incipiente tentativa de esboçar a função histórico-social e instrumental das duas narrativas de dilúvio da Bíblia Hebraica, e pensando diretamente nas comunidades que, perplexas da novidade, ouviam-nas pela primeira vez, uma rememoração provocativa. O sucesso psicológico-social e político-religioso dessas duas empreitadas de controle social, primeiro monárquico, e, posteriormente, de longe, o mais bem sucedido, sacerdotal, fez-me, a respeito do projeto político-platônico de controle social por meio dos mitos,recordar o comentário de Detienne, na obra já citada:

Conheces algum meio", pergunta Sócrates, "para fazer com que se acredite neste mûthus?". Nenhum, responde o interlocutor, "pelo menos para a geração de que falas; mas talvez se consiga persuadir seus filhos, seus descendentes e os homens do futuro (DETIENNE, 1998, p. 174).

\section{REFERÊNCIAS}

APEL, K.-O. Transformação da Filosofia II. O a priori da comunidade de comunicação. São Paulo: Loyola, 2000.

DETIENNE, M. A Invenção da mitologia. Rio de Janeiro: José Olympio, 1998.

EISSFELDT, Otto. The Old Testament. An introduction including the Apocrypha and Pseudepigrapha, and also the works of similar type from Qumran. The history of the formation of the Old Testament.New York e Evanston: Harper and Row, 1966.

FINKELSTEIN, I.; SILBERMAN, N. A. A Bíblia não tinha razão. São Paulo: Girafa, 2003 .

GINZBURG, C. Sinais - raízes de um paradigma indiciário. In: GINZBURG, C. Mitos, emblemas, sinais. Morfologia e histórica. São Paulo, Cia. das Letras, 1989. p. 143-179.

LIVERANI, M. Para além da Bíblia. História antiga de Israel. São Paulo: Paulus e Loyola, 2008. 
RIBEIRO, O. L. A Cosmogonia de Inauguração do Templo de Jerusalém - o Sitz im Leben de Gn 1,1-3 como prólogo de Gn 1,1-2,4a. Tese de Doutorado. Rio de Janeiro: PUC-Rio, 2008a.

RIBEIRO, O. L. A República de Judá nas “visões” de Zacarias - porque o poder não é apocalíptico. Oracula, São Paulo, v. 2, n. 4, p. 1-50, 2006.

RIBEIRO, O. L. A “terra” e "as águas” originais. História e linguagem mítica em Gn 1,1-3. Estudos Bíblicos, Petrópolis, n. 80, p. 40-48, 2003b.

RIBEIRO, O. L. Cântico dos Cânticos (7,10[11]) contra Gênesis 3,16: um caso de intertextualidade programática subversiva. Estudos Teológicos, São Leopoldo, v. 53, n. 2, p. 312-324, 2013.

RIBEIRO, O. L. Como que pelos chifres: o vento na criação, segundo Pr 30,4. Fragmentos de Cultura, Goiânia, v. 15, n. 9, p. 1371-1383, 2005.

RIBEIRO, O. L. Comprar gato por lebre? O “assalto" teológico à abordagem históricofilológica da raiz br' entre os séculos XVIII e XX. Pistis e Praxis, Curitiba, v. 8, n. 1, p. 55$71,2016$.

RIBEIRO, O. L. Dilúvio(s) - as narrativas sacerdotal e pós-sacerdotal da Bíblia Hebraica, em contexto histórico-social. Revista de Cultura Teológica, São Paulo, n. 47, p. 99-136, 2004. Disponível em:

<https://revistas.pucsp.br/index.php/culturateo/article/view/24905/17785>. Acesso em:

RIBEIRO, O. L. Firmamentum - em busca da compreensão semântico-fenomenológica de raqia‘ na Bíblia Hebraica (Parte I). Via Teológica, Curitiba, n. 16, v. 2, p. 7-22, 2008b.

RIBEIRO, O. L. Homo faber. O contexto da “criação” em Gn 1,1-3. Rio de Janeiro: Mauad, 2015.

RIBEIRO, O. L. Imagem e Forma. Análise semântico-fenomenológica de tselem e demut na Bíblia Hebraica. Via Teológica, Curitiba, n. 8, p. 103-128, $2003 \mathrm{c}$.

RIBEIRO, O. L. Vento Tempestuoso: um ensaio sobre a tradução e a interpretação de Gn 1,2 à luz de Jr 4. Fragmentos de Cultura, Goiânia, v. 12, n. 4, p. 573-598, 2002.

RIBEIRO, O. L. Vento Tempestuoso: novas reflexões sobre Gn 1,2 à luz da Fenomenologia da Religião. Revista Teológica Londrinense, Londrina, n. 5, p. 103-169, 2003 a.

SCHÖKEL, L. A. Dicionário Bíblico Hebraico-Português. São Paulo, Paulus, 1997. 